University of Nebraska - Lincoln

DigitalCommons@University of Nebraska - Lincoln

Faculty Publications from the Harold W. Manter Laboratory of Parasitology

7-2005

\title{
Diphyllobothrium fayi n. sp. (Cestoda: Diphyllobothriidae) from the Pacific Walrus, Odobenus rosmarus divergens
}

Robert L. Rausch

University of Washington, rausch@uw.edu

Follow this and additional works at: https://digitalcommons.unl.edu/parasitologyfacpubs

Part of the Parasitology Commons

Rausch, Robert L., "Diphyllobothrium fayi n. sp. (Cestoda: Diphyllobothriidae) from the Pacific Walrus, Odobenus rosmarus divergens" (2005). Faculty Publications from the Harold W. Manter Laboratory of Parasitology. 342.

https://digitalcommons.unl.edu/parasitologyfacpubs/342

This Article is brought to you for free and open access by the Parasitology, Harold W. Manter Laboratory of at DigitalCommons@University of Nebraska - Lincoln. It has been accepted for inclusion in Faculty Publications from the Harold W. Manter Laboratory of Parasitology by an authorized administrator of DigitalCommons@University of Nebraska - Lincoln. 
Comp. Parasitol.

72(2), 2005, pp. 129-135

\title{
Diphyllobothrium fayi n. sp. (Cestoda: Diphyllobothriidae) from the Pacific Walrus, Odobenus rosmarus divergens
}

\author{
ROBERT L. RAUSCH \\ Department of Pathobiology and Department of Comparative Medicine, Box 357190, University of Washington, \\ Seattle, Washington 98195-7190, U.S.A. (e-mail: rausch@u.washington.edu)
}

ABSTRACT: An independent species of cestode of the genus Diphyllobothrium Cobbold, 1858, known only from the Pacific walrus, Odobenus rosmarus divergens Illiger, has been incorrectly designated Diphyllobothrium cordatum (Leuckart, 1863) in the literature since 1955. That cestode is described in this study as Diphyllobothrium fayi $\mathrm{n}$. sp. on the basis of specimens obtained from walruses from the northern Bering Sea and the Arctic Ocean. It is distinguished readily from D. cordatum by its much larger strobila of different form and by a range of morphological characteristics of taxonomic significance in the reproductive organs. Comparisons were made with specimens of $D$. cordatum from the bearded seal, Erignathus barbatus (Erxleben), its typical host. Diphyllobothrium fayi has been recorded only from the Pacific walrus. Although that mammal feeds mainly on mollusks and other benthic invertebrates, records of cestodes from it suggest that fishes potentially harboring plerocercoids are frequently consumed.

KEY WORDS: Cestoda, Diphyllobothriidae, Diphyllobothrium fayi n. sp., Diphyllobothrium cordatum (Leuckart, 1863), Pacific walrus, bearded seal.

Of the 37 species of the genus Diphyllobothrium Cobbold, 1858, recognized in the recent monograph of the Diphyllobothriidae by Kamo (1999), only 2, Diphyllobothrium cordatum (Leuckart, 1863) and Diphyllobothrium roemeri (Zschokke, 1903), were listed as occurring in walruses, Odobenus rosmarus (L.). I have found that a third species of Diphyllobothrium occurs in the Pacific walrus, Odobenus rosmarus divergens Illiger. That cestode long has been confused with $D$. cordatum, a common helminth in the bearded seal, Erignathus barbatus (Erxleben), and recorded from other phocids, but which has been found rarely in the walrus. The present article reviews the taxonomic history of $D$. cordatum and establishes the specific independence of the cestode from the Pacific walrus.

In view of the convoluted circumstances involved in the description and redescriptions of $D$. cordatum, a brief historical chronology of the records of that cestode is provided in this study. Bothriocephalus cordatus Leuckart, 1863 (=Diphyllobothrium cordatum [Leuckart, 1863]) was described on the basis of specimens from dogs and from a person in Greenland. According to Leuckart (1863, p. 439), the cestodes were obtained by the Royal Danish Inspector for North Greenland, Justizrath Olrik, and transmitted to Leuckart by the Danish zoologist J. Steenstrup (Japetus Steenstrup, 1813-1897). Some of the same specimens were studied by Krabbe ( 1865 , p. 377), who provided additional information about their provenance. Krabbe stated that they had been obtained from Olrik's 6 dogs in 1859 and 1860. Another collection (3 October 1860) in Greenland, by
District Doctor Pfaff, consisted of 24 cestodes from 3 of 4 dogs. Those cestodes, collected at Godhavn, probably constituted the type material of $D$. cordatum studied by Leuckart; he stated (1863, p. 439) that "Im Ganzen konnte ich vielleicht einige zwanzig Exemplare vergleichen, junge und alte, unter denen aber nur eines von einem Menschen stammte." The latter had been expelled by a woman residing in Godhavn, north Greenland (Leuckart, 1863, p. 439). On 24 July 1860, Dr. Pfaff found 4 cestodes of the genus Diphyllobothrium in the small intestine of a bearded seal at Disco, Greenland, of which the largest was $1 \mathrm{~cm}$ in width and more than $1 \mathrm{~m}$ in length. Krabbe (1865) reported further that, on 7 November 1863, Colony-Director Zimmer obtained 3 specimens of $B$. cordatus from a walrus, Trichechus Rosmarus (= Odobenus rosmarus [Linnaeus, 1758]) (see Fay, 1982, for a review of the taxonomy of walruses), at Egedesminde, Greenland. Zschokke (1903, p. 5) examined cestodes collected by Römer and Schaudinn from a harbor seal, Phoca vitulina L., 20 miles west of Ross Island, North Spitzbergen. Those cestodes, of which several hundreds were present, had a maximal length of $120 \mathrm{~mm}$. Zschokke identified them as Dibothriocephalus cordatus, but morphological details given in his brief description indicate that they represented another species. In those collections from Greenland, only those from dogs and illustrated by Leuckart (1863) can be certainly designated as $D$. cordatum.

Some of the same material (from Greenland) has been studied by other helminthologists. In his review 
of the taxonomy of cestodes from pinnipeds in the Arctic, Markowski (1952) studied specimens of $D$. cordatum from 2 walruses and a bearded seal, of which Olrik was listed as collector of those from 1 walrus and the seal. Markowski provided a detailed redescription of that cestode, based mainly on a specimen collected by Olrik in 1864 from 1 walrus. Evidently, his redescription was the first reliable record of $D$. cordatum from that mammal.

More recently, Andersen (1987) examined specimens of $D$. cordatum in the collection of the British Museum (Natural History), evidently those studied by Markowski (1952). She provided (p. 415, fig. 8) a photograph of a typical strobila of $D$. cordatum and referred to Markowski's work (1952) for morphological details. Kamo (1999) reproduced Andersen's photograph and also referred to Markowski (1952) for details. Rausch and Adams (2000) briefly discussed morphological characteristics of that cestode and because Leuckart's collection in Leipzig, Germany, had been destroyed during World War II, proposed that his illustration of the strobila (Leuckart, 1863 , p. 446 , fig. 142) be designated the lectotype. The information provided by Leuckart (1863) and Markowski (1952) obviously indicates that at least 2 species of Diphyllobothrium were represented among the early collections from dogs, marine mammals, and a person in Greenland; but other than D. cordatum none can be identified.

In his monograph on the helminth fauna of marine mammals, Deliamure (1955) provided a description of 1 specimen of a cestode from the Pacific walrus. That specimen, $91 \mathrm{~cm}$ in length and very much contracted, he identified as $D$. cordatum. His data and illustrations show otherwise. Subsequently, Iurakhno (1971) identified cestodes from walruses in the Chukchi Sea as D. cordatum sensu Deliamure. Evidently, Markowski's accurate redescription (Markowski, 1952) of D. cordatum was not available to Deliamure at the time his monograph (Deliamure, 1955) was completed; it was not included in the literature cited. The erroneous identification was perpetuated in the succeeding volume concerning the Diphyllobothriidae by Deliamure et al. (1985), wherein the description and figures of " $D$. cordatum" were reproduced from Deliamure's (1955) monograph.

Diphyllobothrium cordatum is a characteristic and, as noted above, very common cestode in the bearded seal in the Bering Sea and in the Arctic Ocean along the northern coast of Alaska. It is readily identified macroscopically on the basis of the unusual form of its strobila, as shown by Leuckart (1863, p. 446). The cestode from the Pacific walrus represents an independent species, which is described in this study as Diphyllobothrium fayi n. sp., based on specimens collected in the northern Bering Sea and Arctic Ocean.

\section{MATERIALS AND METHODS}

The following description is based on 8 cestodes from the Pacific walrus: 2 from an adult male (original No. 6855), killed by Siberian Yupik hunters near the northern coast of St. Lawrence Island, Bering Sea, on 28 April 1950 (leg. RLR); 2 from a young female walrus (No. 13017), ca. 2 yr old (weight $192 \mathrm{~kg}$ ), killed by Iñupiaq hunters in the western Beaufort Sea $24 \mathrm{~km}$ north of Nullagvik (Skull Cliff) (southwest of Barrow, Alaska) on 11 August 1953 (leg. RLR); and 4 from an adult female (No. 44290) collected in the northern Bering Sea $\left(62^{\circ} 46^{\prime} 1^{\prime \prime} \mathrm{N} ; 173^{\circ} 9^{\prime} 4^{\prime \prime} \mathrm{W}\right)$ on 24 April 1979 (leg. F. H. Fay and L. M. Shults). Comparisons were made with numerous specimens of $D$. cordatum from bearded seals obtained in the Bering Sea and along the arctic coast of Alaska. In the field, the cestodes were relaxed in water and fixed in a $10 \%$ solution of formalin, after which, in the laboratory, they were stained in acetic carmine or Ehrlich's acid hematoxylin, dehydrated in ethanol, cleared in terpineol, transferred to xylene, and mounted permanently on slides. Entire strobilae, because of their size, were not preserved on slides, but anterior portions, with scoleces, and selected series of proglottids were stained and prepared for permanent usage on slides. Sagittal and transverse sections were cut by hand. From 1 cestode (walrus No. 13017), gravid proglottids were processed by the paraffin-embedding method, and serial transverse sections were cut at 7 and 15 $\mu \mathrm{m}$ and stained in hematoxylin-eosin. From selected proglottids, the tegument and underlying layers of musculature were removed ventrally or from both surfaces to facilitate study of internal organs. Testes were counted with use of a grid, and 3 counts from single proglottids were made to compensate for possible error. Cestodes from bearded seals were processed in the same manner, and both sagittal and transverse sections also were studied. All dimensions are given in micrometers unless otherwise indicated.

\section{Diphyllobothrium fayi $\mathrm{n} . \mathrm{sp}$. (Figs. 1-4)}

\section{Description}

Strobila robust, ranging in length from $1.36 \mathrm{~m}$ (without apolysis) to at least $4.67 \mathrm{~m}$, with a maximal width of $15 \mathrm{~mm}$. Of 4 cestodes from walrus No. 44290, 2 strobilae had been broken; the combined lengths of all 4 totaled $8.69 \mathrm{~m}$, with 1,811 proglottids, giving a mean length of $2.17 \mathrm{~m}$ and a mean of 453 proglottids. Maximal thickness of strobila at midline 1.7 to $2.5 \mathrm{~mm}$. Strobila somewhat attenuated anteriorly, widening rapidly. Proglottids weakly craspedote; strobilar margins essentially parallel throughout. Scolex broadly lanceolate in lateral view, widest near middle; 1.50 to $2.3 \mathrm{~mm}$ in length by 1.40 

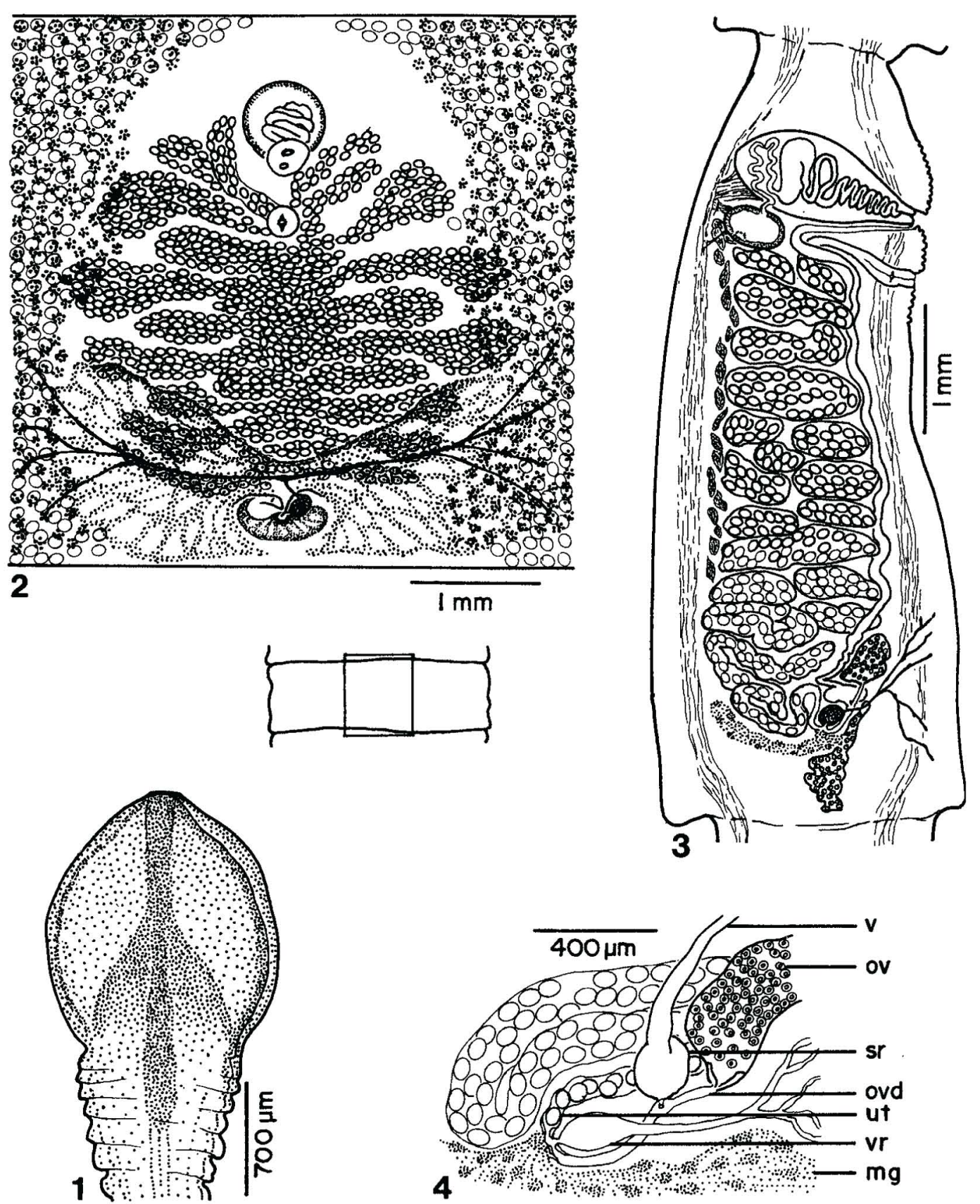

Figures 1-4. Diphyllobothrium fayi n. sp. 1. Scolex. 2. Central portion of gravid proglottid, ventral view. Insert shows area of proglottid represented. 3. Relationships of organs as seen in medial sagittal section. 4. Female genital ducts, ventral view. v, vagina; ov, ovary; sr, seminal receptacle; ovd, oviduct; ut, uterus; vr, vitelline reservoir; mg, Mehlis' gland.

to $1.87 \mathrm{~mm}$ in maximal width. Neck absent. More anterior gravid proglottids about twice as wide as long; posteriad becoming more or less quadrate. Two longitudinal excretory canals observed, 50 to 70 in diameter, situated bilaterally adjacent to longitudinal nerves, about 400 medial to lateral margins of proglottids. Strobila with median, longitudinal groove ventrally, in which opening of genital atrium appears 
as transverse groove near anterior margin of proglottid. Genital Anlagen first visible from 13th to 42nd proglottid posterior to scolex. Following earlier appearance of cirrus sac and uterus, testes appearing abruptly in 36th to 65 th proglottids. Opening of genital atrium 230 to 300 in transverse dimension. Ventrally, surface of proglottid surrounding genital atrium with numerous papillae, distributed more or less uniformly 30 to 50 apart, and covering rounded area 1.1 to $1.3 \mathrm{~mm}$ in length by about $1.5 \mathrm{~mm}$ in width, extending from about 100 posterior to uterine pore anteriad to about 200 from anterior margin of proglottid. Papillae also lining interior surface of genital atrium dorsad to level of openings of cirrus sac and vagina. Cirrus sac pyriform, widest near proximal (dorsal) end, with long axis directed anterodorsad. Cirrus sac 840 to $1.50 \mathrm{~mm}$ in length by 460 to 750 in maximal diameter (mean $1.12 \mathrm{~mm}$ by 615 ), opening anterior to vagina. Spherical to subspherical seminal vesicle 350 to 610 in dorsoventral dimension by 300 to 400 in maximal diameter (mean 437 by 345), apposed to posterior wall of cirrus sac near proximal end. Duct from seminal vesicle extending posterodorsad to entry into cirrus sac. Wall of seminal vesicle about 100 thick, with numerous muscle fibers arising around proximal end and fusing with fibers of adjacent layer of longitudinal muscle. Testes numbering about 3,158 per proglottid, forming dorsal layer in 2 lateral fields. Single row of testes occasionally extending across proglottid near anterior margin; usually not confluent anteriorly. Testes not confluent at posterior margin of proglottid; may or may not slightly overlap posterolateral margins of ovarian lobes and lateral ends of uterine loops. Testes spherical to subspherical, 90 to 157 in greater diameter by 80 to 130 (mean 124 by $104)$; arranged essentially in single layer, but may overlap slightly on both sides of midline where thickness of parenchyma is greatest. Vas deferens taking undulating course dorsally near midline, to seminal vesicle. Vagina 50 to 70 in diameter near opening in genital atrium, extending dorsad along posterior surface of cirrus sac to ventral surface of seminal vesicle, there turning ventrad; after approaching ventral surface of proglottid, vagina turns posteriad, taking sinuous course on midline more or less ventral to uterine loops to seminal receptacle near posterior end of proglottid. Bilobed ovary reticulate, situated transversely at posterior end of proglottid; ovarian lobes connected by isthmus about 350 in width at midline of proglottid. Ovary 2.47 to $3.85 \mathrm{~mm}$ wide (mean $2.62 \mathrm{~mm}$ ); maximal lengths of ovarian lobes 740 to $1.5 \mathrm{~mm}$ (mean 828). Lateral margins of ovarian lobes extending 140 to 450 (mean 242) laterad beyond ends of uterine loops. Vitellaria abundant, closely apposed and, in transverse section, forming subcuticular layer 130 to 150 deep; individual follicles 90 to 160 in length by 40 to 90 in diameter (mean 132 by 52). Vitelline follicles extending mediad slightly over lateral margins of ovarian lobes; also overlapping ends of uterine loops when latter are much distended by eggs. Vitelline follicles not confluent across anterior or posterior ends of proglottids. Uterine pore situated ventrally at or near midline of proglottid, 250 to 420 posterior to opening of genital atrium. Uterine pore 200 to 250 in diameter; when not containing eggs, terminal end of uterus about 200 in diameter. Uterine sphincter well developed. Uterine loops greatly distended with eggs forming compact rosette occupying about two thirds of length of proglottid. Lateral ends of uterine loops, usually 6 or 7 bilaterally, 330 to 460 in diameter; 2 anteriormost loops extending anteriad about to midline of cirrus sac in ventral view. Eggs ellipsoidal, 74.5 to 90.7 in length by 47.0 to 58.3 in maximal diameter (mean 83.6 by 54.5 ) (175 eggs measured). Operculum 19.5 to 27 in diameter (mean 24.4).

\section{Taxonomic summary}

Type host: Pacific Walrus, Odobenus rosmarus divergens Illiger.

Type locality: Northern Bering Sea $\left(62^{\circ} 46^{\prime} 1^{\prime \prime} \mathrm{N}\right.$; $\left.173^{\circ} 9^{\prime} 4^{\prime \prime} \mathrm{W}\right)$.

Site of infection: Small intestine.

Type specimens: Holotype, United States National Parasite Collection, Beltsville, Maryland, USNPC 095440.00; Paratype, USNPC 095441.00.

Etymology: This cestode is named in honor of the late Francis H. Fay, who contributed importantly to knowledge of helminths and marine mammals in Alaska and Siberia.

\section{Remarks}

The 4 cestodes illustrated by Leuckart (1863, p. 446, fig. 142) as "Jugendformen von Bothiocephalus cordatus in natürlicher Grösse" were contracted strobilae of fully developed specimens of that cestode, well within the normal size-range of gravid specimens found in bearded seals in waters around Alaska. According to Leuckart, the illustrated specimens ranged in length from 30 to $100 \mathrm{~mm}$. The shortest had 140 proglottids; for the remaining 3, proglottids ranged from 125 to 154 in number. 
(Examination of Leuckart's fig. 142, portraying 4 cestodes "in natural size" from dogs, when enlarged, revealed that the largest actually measured $103 \mathrm{~mm}$ in length, with 226 proglottids, rather than 154, as stated.) Apolysis evidently does not occur in $D$. cordatum; the strobila of that cestode invariably is strongly attenuated posteriorly, the terminal segment being very small (as shown in Leuckart's fig. 142). Leuckart (1863, p. 441, fig. 138, incorrectly designated fig. 139) also provided an illustration of a cestode "in natural size" $(26 \mathrm{~cm}$ in length with 300 proglottids) (strongly contracted) from a person. Leuckart stated that at first sight the cestode appeared to be not insignificantly different (“... nicht unbeträchtlich verschieden") from those in dogs. That cestode, in its more massive strobila, larger and longer proglottids, and in that apolysis had occurred at a level of its maximal width, clearly differed from D. cordatum. The reproduction of that figure (rather than that of the cestodes from dogs) as portraying D. cordatum in some subsequent publications (cf. Cobbold, 1879, p. 110; Neveu-Lemaire, 1936, p. 405) was further misleading.

Diphyllobothrium fayi is readily distinguished from $D$. cordatum by its much longer strobila of different form, greater size of proglottids, larger eggs, and major differences in form and relationships of genital organs. Morphologically, D. fayi differs significantly from all the species of Diphyllobothrium of comparable large size known from marine mammals. For comparisons, an abbreviated description of $D$. cordatum is included in this study (see also the description by Markowski, 1952).

\section{Diphyllobothrium cordatum (Leuckart, 1863)}

\section{Description}

Maximal length of strobila about $35 \mathrm{~cm}$ but usually 10 to $20 \mathrm{~cm}$; maximal width about $6 \mathrm{~mm}$ in well relaxed specimens. Strobila thin and more or less translucent in relaxed specimens; maximal thickness 650 to 850 at midline. Proglottids craspedote, numerous (e.g., 597 proglottids in specimen $34 \mathrm{~cm}$ in length); degree of serration of strobilar margins increasing posteriad. Scolex cordate, 71 to 92 in length by 90 to 107 in maximal width near posterior margin. Neck usually not discernible; in well-relaxed specimens, segmentation becomes apparent approximately 300 posterior to scolex. Apolysis not occurring. Proglottids markedly wider than long in anterior approximately two-thirds of strobila, including most of gravid proglottids; last approximately one third of strobila strongly attenuated posteriad, with increasing relative length of proglottids. Mature eggs first found in uterus in proglottids at or beyond middle of strobilar length. Genital Anlagen usually appearing in about 50th proglottid posterior to scolex. Opening of genital atrium 20 to 25 posterior to anterior margin of proglottid; uterine pore 40 to 80 posterior to opening of genital atrium. Ventral surface of proglottid around genital atrium with papillae arranged in circular area about 400 in diameter, extending from uterine pore anteriad nearly to anterior margin of proglottid. Cirrus sac, opening anterior to vagina, pyriform with proximal end rounded, 590 to 752 in length by 290 to 349 in maximal diameter (mean 625 by 306 ); long axis of cirrus sac directed anterodorsad, with distal end extending to or slightly beyond anterior margin of proglottid. Seminal vesicle subspherical to spherical, 151 to 200 in greater diameter by 150 to 195 (mean 176 by 169), situated posterior to cirrus sac near proximal end. Testes abundant, arranged in layers 2-3 deep; not confluent across anterior or posterior ends of proglottid, slightly overlapping margins of ovary but not ends of uterine loops. Testes 17 to 51 in greater diameter (mean 31). Vagina thick-walled, extending dorsad from genital atrium past seminal vesicle to internal margin of dorsal layer of longitudinal musculature, there turning ventrad and extending nearly to ventral surface of proglottid, then turning posteriad. Bilobed ovary reticulate, 1.04 to $1.50 \mathrm{~mm}$ in width, situated at posterior margin of proglottid. Vitellaria abundant, closely apposed; in ventral view measuring 27 to 41 by 19.5 to 31.7 (mean 35.8 by 26.8), forming dense layer 60 to 100 thick as seen in transverse sections. Vitelline follicles not confluent across anterior margin of proglottid; often broadly confluent posterior to ovary in oldest proglottids. Follicles overlapping ends of uterine loops and lateral margins of ovary. Uterine loops not closely apposed; usually 5 or 6 in number bilaterally; posteriormost 1 or 2 loops extending somewhat posterolaterad, overlapping ovarian lobes bilaterally. Eggs ellipsoidal, 51.0 to 70.6 in length by 36.5 to 58.0 (mean 64.6 by 40.0). Operculum 19 to 22 in diameter.

\section{Voucher specimens}

Host: Bearded seal, Erignathus barbatus (Erxleben). Localities: Barrow, Alaska, 15 May 1949 (leg. RLR), USNPC 095442.00; $39 \mathrm{~km}$ south-southwest of Gambell, St. Lawrence Island, Bering Sea, 16 May 1958 (leg. FHF), USNPC 095442.00.

Site of infection: Small intestine (usually present in very large numbers). 


\section{DISCUSSION}

The information provided by Leuckart (1863) was somewhat incomplete, making possible certain identification of only $D$. cordatum from dogs in Greenland. He mentioned (p. 439) a cestode, apparently from a dog, that had a length of $115 \mathrm{~cm}$, with about 660 proglottids, but it was not described in detail. That cestode represented a species other than $D$. cordatum, but it might have been understood by Deliamure as an indication that the latter species attains a considerable length. On the basis of the information available to him, it seems unremarkable that Deliamure (1955) was misled in his identification of the cestode from the walrus as D. cordatum. Moreover, his single specimen was strongly contracted, causing distortion of the relationships of organs as observed only in thick sections. That condition further increased the thickness of an already rather massive strobila, preventing the examination of internal morphological details in complete stained proglottids (cf. Deliamure, 1955, p. 142). That the incorrect identification of the cestode in the walrus was not recognized before we (F. H. Fay and I) first studied it in 1960-1961 may be attributed to a lack of specimens from that mammal and to unquestioning acceptance of authoritative publications.

Diphyllobothrium fayi is known only from the Pacific walrus, but host-specificity is usually not characteristic of cestodes of the genus Diphyllobothrium in marine mammals. For example, several species typically occurring in those mammals have now been reported from people (Yamane and Shiwaku, 2003, and others). The diet of walruses consists mainly of bivalves, although other benthic invertebrates of various species have been identified in contents of their stomachs (Fay, 1982, p. 145). Fay reported (p. 153) that remains of fishes were identified in only 2 of 240 stomachs examined. However, the earlier records of D. cordatum from walruses (Markowski, 1952) and the finding of what is described here as D. fayi in $10 \%$ of 95 animals in the Chukchi Sea (Iurakhno, 1971) indicate that fishes potentially harboring plerocercoids are often consumed by them.

\section{ACKNOWLEDGMENTS}

The collection of helminths from marine mammals by me and my coworkers in Alaska during the period 1949-1975 was accomplished through the generous cooperation of the Siberian Yupik residents of St. Lawrence Island and the Iñupiat on the arctic coast, who kindly permitted us to participate in hunting expeditions and who provided many animals for examination. The first 2 walruses found to be infected by the cestode described in this study were examined on expeditions with the late John Apangalook of St. Lawrence Island and the late Alfred Hopson of Barrow. Yosuke Yamane generously provided for comparison cestodes from marine mammals from seas near Japan. Virginia R. Rausch kindly prepared the figures. I am deeply grateful for those contributions.

\section{LITERATURE CITED}

Andersen, K. I. 1987. A redescription of Diphyllobothrium stemmacephalum Cobbold, 1858 with comments on other marine species of Diphyllobothrium Cobbold, 1858. Journal of Natural History 21:411-427.

Cobbold, T. S. 1879. Parasites; A Treatise on the Entozoa of Man and Animals, Including Some Account of the Ectozoa. J. and A. Churchill, London, England. 508 pp.

Deliamure, S. L. 1955. Gel'mintofauna morskikh mlekopitaiushchikh $\mathrm{v}$ svete ikh ekologii i filogenii. K. I. Skriabin, ed. Akademiia Nauk SSSR, Moskva, SSSR. $517 \mathrm{pp}$.

Deliamure, S. L., A. S. Skriabin, and A. M. Serdiukov. 1985. Difillobotriidy-lentochnye gel'minty cheloveka, mlekopitaiushchikh i ptits. V. E. Sudarikov, ed. Osnovy Tsestodologii. Vol. XI. Nauka, Moskva, SSSR. 200 pp.

Fay, F. H. 1982. Ecology and biology of the Pacific walrus, Odobenus rosmarus divergens Illiger. North American Fauna 74, United States Department of the Interior, Fish and Wildlife Service, Washington, D.C. 279 pp.

Iurakhno, M. V. 1971. Gel'minty promyslovykh mlekopitaiushchikh Beringova i Chukotskogo morei. Dissertation. Vsesoiuznyi Ordena Trudovogo Krasnogo Znameni, Institut Gel'mintologii Imeni Akademika K. I. Skriabina, Moskva, SSSR. 24 pp.

Kamo, H. 1999. Guide to Identification of Diphyllobothriid Cestodes. Gendai Kikaku, Tokyo, Japan. 146 pp. (In Japanese).

Krabbe, H. 1865. Helminthologiske Undersøgelser i Danmark og paa Island, med saerligt Hensyn til Blaereormlidelserne paa Island. Advance separate, Det Køngelige Danske Videnskabernes Selskabs Naturvidenskabelige og Mathematiske Afhandlinger, Afd. 5.R. 1868, 7:1-117. København, Denmark.

Leuckart, R. 1863. Die menschlichen Parasiten und die von ihnen herrührenden Krankheiten. Ein Hand- und Lehrbuch für Naturforscher und Aerzte. Vol. I. Winter'sche Verlagshandlung, Leipzig und Heidelberg, Germany. 766 pp.

Markowski, S. 1952. The cestodes of pinnipeds in the Arctic and other regions. Journal of Helminthology 26:171-214.

Neveu-Lemaire, M. 1936. Traité d'helminthologie médicale et vétérinaire. Vigot Frères, Paris, France. 1514 pp.

Rausch, R. L., and A. M. Adams. 2000. Natural transfer of helminths of marine origin to freshwater fishes, with observations on the development of Diphyllobothrium alascense. Journal of Parasitology 86:319-327.

Yamane, Y., and K. Shiwaku. 2003. Diphyllobothrium nihonkaiense and other marine-origin cestodes. Pages 
245-259 in M. Otsuru, S. Kamegai, and S. Hayashi, eds. Progress of Medical Parasitology in Japan. Vol. 8, chapter III. Meguro Parasitological Museum, Tokyo, Japan. Zschokke, F. 1903. Die arktischen Cestoden. Pages 1-32 in F. Römer und F. Schaudinn, eds. Fauna Arctica. Eine
Zusammenstellung der arktischen Tierformen, mit besonderer Berücksichtigung des Spitzbergen-Gebietes auf Grund der Ergebnisse der Deutschen Expedition in das Nördliche Eismeer im Jahre 1898. Vol. 3, 1 Lieferung, 2 plates, 23 figs. Verlag Gustav Fischer Jena, Germany. 